
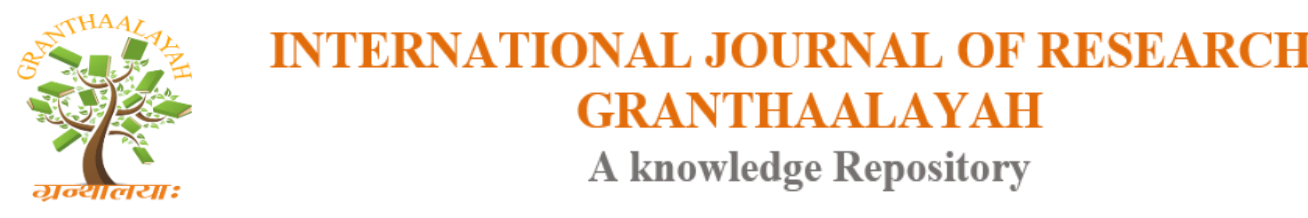

Science

\title{
PLASTIKNOLOGY DEVELOPMENT AND UTILIZATION AMONG PERSON WITH DISABILITY (PWDs) IN SINACABAN, MISAMIS OCCIDENTAL
}

\author{
Doncillo Ma. Liberty B. ${ }^{1}$, Naelga Sofia C. ${ }^{2}$ \\ ${ }^{1}$ Graduate School, College of Science and Technology Education University of Science and \\ Technology, Cagayan de Oro City, Philippines \\ ${ }^{2}$ Master of Arts in home Economics, Department of TLE \& Technician Teacher Education, \\ College of Science and Technology Education, University of Science and Technology of \\ Southern Philippines, Cagayan de Oro City, Philippines
}

\begin{abstract}
In response to the global community problem on solid waste management and the empowerment of the persons with disability (PWDs), this study is focused on Plastiknology development and utilization among persons with disability (PWDs) in Sinacaban, Misamis Occidental, Philippines. The study employed IPO (input process output) model using the respondents' profile as the input variables and sanitation, sorting, cutting, folding and connecting skills as the process variables. Plastiknology products such as coin purse, clutch bag, wallet and placemats serves as the output variables. Using descriptive statistics, the mean, standard deviation, frequency, percentage and percentage distribution are used to describe each variable. Regression analysis was used to test the input and process variables' influence on the creation of the output products. Statistics shows minimal background on handicrafts, but interest in trainings is high. Active participation on livelihood trainings was shown in respondents' positive attendance, attitude and product construction. As a result, there was no significant difference between self-evaluated and postevaluated skills. Qualitatively, the products of the partcipants are promising and well-constructed. It was therefore recommended that the national and local institutions shall provide livelihood assistance to special sectors such as PWDs by facilitating the continuity of this livelihood program.

Keywords: Plastiknology; Handicrafts; Home Crafts; PWDS; IPO; Solid Waste Management.

Cite This Article: Doncillo Ma. Liberty B., and Naelga Sofia C.. (2018). "PLASTIKNOLOGY DEVELOPMENT AND UTILIZATION AMONG PERSON WITH DISABILITY (PWDs) IN SINACABAN, MISAMIS OCCIDENTAL." International Journal of Research Granthaalayah, 6(7), 382-398. https://doi.org/10.29121/granthaalayah.v6.i7.2018.1317.
\end{abstract}

\section{Introduction}

The global community recognizes that Solid Waste Management is an issue that requires serious attention. The aggressive pursuit for economic growth, by developing countries like the 
Philippines has resulted in the manufacture, distribution and use of products and generation of wastes that contribute to environmental degradation and global climate change. This is heavily manifested in the frequent and intense floods the country is experiencing from devastating typhoons which may be claimed are due to climate change.

Despite government efforts, however, poor solid waste management in the Philippines is still prevalent since open and controlled dumps are being used in the country, which pose great threats on the country's environment and public health. (JICA Waste Characterization Study, September, 2003)

Anchored on the present issues on hazards that go with the improper disposal of plastic wastes, the need for an alternative means to manage such wastes then arise. An extension project on recycling common household plastics (coffee sachets, plastic bags, etc.) with persons with disability (PWDs) came into view.

The extension project is expected to enhance awareness of persons with disability (PWDs) on the utilization of plastic bags and other plastics (Polyethylene) so that it will help reduce problems related to its usage, and recycle such materials into home crafts and give more emphasis on the development of the product.

Applying the $3 \mathrm{R}$ method in minimizing waste products, these polyethylene plastic wastes were sanitized, sorted, folded, cut, connected and knotted to produce handicraft products.

It is in this context that the study on Plastiknology Development and Utilization among Persons with Disability (PWDs) in Misamis Occidental came into view and was realized. This aims to recycle polyethylene wastes that would enable Persons with Disability (PWDs) to produce handicraft outputs which somehow would help their source of livelihood by augmenting income generation. Application of specific skills in oripoly, macramé and crochet using simple hand tools was introduced and used during the training.

This study is based on the concept of waste management through recycling common household plastics called "Plastiknology" with Persons with Disability (PWD). The Philippine Ecological Solid Waste Management Act of 2000, defines recycling as "the treating of used or waste materials through a process of making them sustainable for beneficial use and for other purposes, and includes any process by which solid waste materials are transformed into new products in such a manner that the original products may lose their identity". It is differentiated from reuse in which there are no alterations of the physical or chemical characteristics of the recovered material.

On the other hand, a policy of equalizing opportunities for people with disabilities, maintained by United Nations and other international organizations, is based on the core concept of new approach to social order which is, social integration aimed at creating 'a society for all', "where every individual, each with rights and responsibilities, has an active role to play". The turning-point in developing new approach to social policy for people with disabilities (SPPD) is a new definition of disability as a social phenomenon, formed by society. 
One of the main tasks of social integration is protection and full integration of vulnerable and disadvantaged groups and persons in economic and social spheres of society, including inclusive and equal access to education, information, technologies and know-how. Thus, empowering persons with disability to be an active part of the circular economy.

Input Variable

\begin{tabular}{|ll|}
\hline $\begin{array}{l}\text { Profile of } \\
\text { respondents } \\
\text { 1. }\end{array}$ \\
2. & Gge \\
3. & Civil Status \\
4. & $\begin{array}{l}\text { Types of } \\
\text { disability }\end{array}$ \\
5. & $\begin{array}{l}\text { Attendance } \\
\text { in Various } \\
\text { Trainings }\end{array}$ \\
6. & $\begin{array}{l}\text { Interest in } \\
\text { handicrafts }\end{array}$ \\
7. & $\begin{array}{l}\text { Background } \\
\text { in } \\
\text { handicrafts } \\
\text { dypes of } \\
\text { disability }\end{array}$ \\
\hline
\end{tabular}

Process Variable

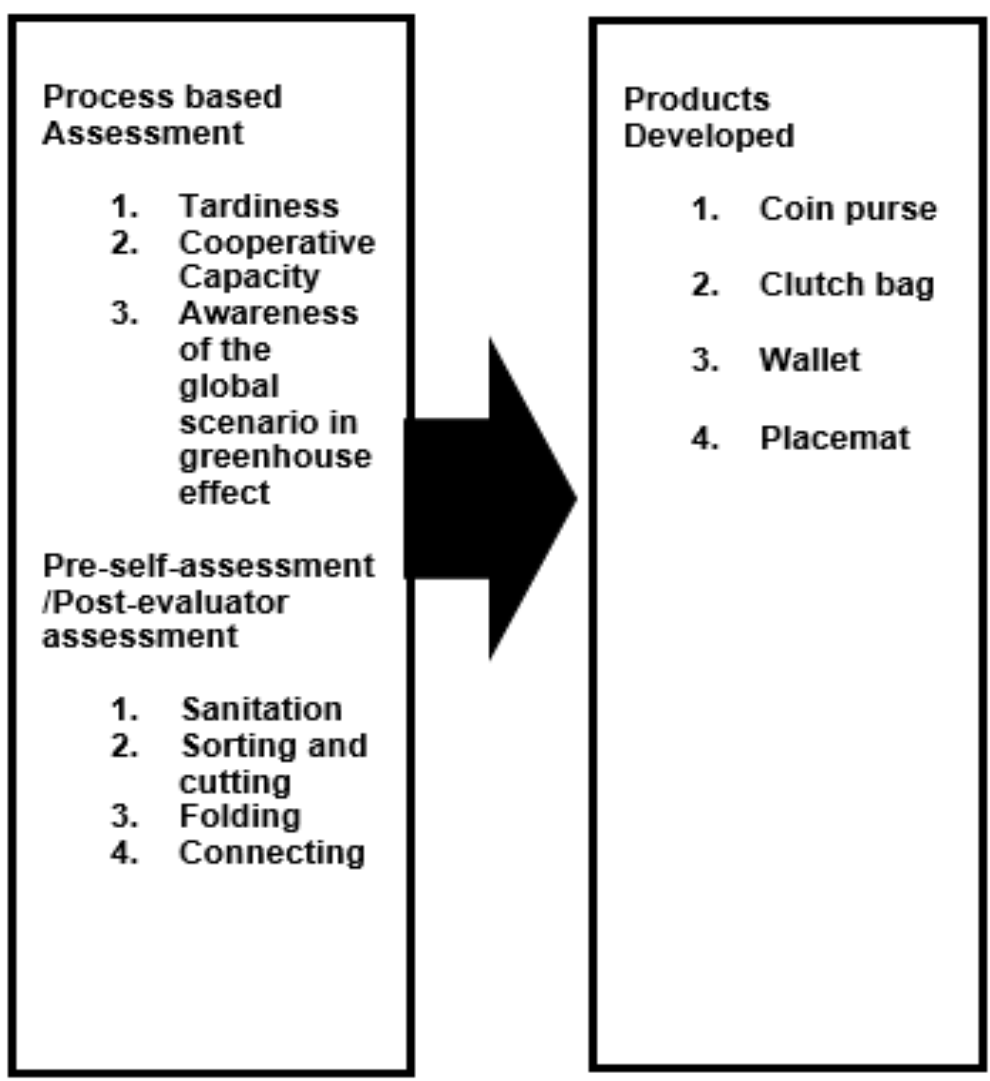

Figure 1: Shows the Input, Process and Output of the Study

\subsection{Statement of the Problem}

1. What is the profile of the respondents in terms of:

- Age

- Gender

- Civil status

- Types of disability

- Attendance in previous livelihood trainings

- Interest in handicrafts

- Background in handicrafts

- Types of disabilities 
2. What is the level of participation of PWDs in the development of Plastiknology in terms of:

- Tardiness

- Cooperative Capacity

- Awareness of the global scenario in greenhouse effect

3. What is the Pre-self- assessment and Post-evaluators-assessment of the respondents in terms of:

- Sanitation

- Sorting and Cutting

- Folding

- Connecting

4. Is there a significant difference between Pre-self-assessment and Post-evaluators assessment of the respondents in terms of: Sanitation, Sorting and cutting, Folding, Connecting?

5. To what extent does input and process variables explain the output variable?

6. What are the innovated products generated and developed by persons with disability (PWDs)?

\subsection{Significance of the Study}

This study is beneficial to the following:

Persons with Disability (PWD). The study recognizes the capability of persons with disability to improve self-worth by acquiring livelihood skills in order to become small scale entrepreneurs, gain independence and improve way of life.

Technology Teachers. This will enhance awareness on how the present issues on environment and waste management will be dealt with and at the same time, serve as reference in teaching handicraft subjects. Furthermore, become empowered and sensitive and responsive enough to accommodate prospect students with different abilities or differently abled individuals.

National and Local Institutions. This will serve as livelihood assistance to special sectors such as persons with disability (PWD). It could also be an alternative measure to waste management issues.

Future Researchers. This research will help the future researchers as their reference for future studies.

Significant Others. To gain support from because PWDs cannot do it without the help of those who serve as their primary source of inspiration and motivation. 


\subsection{Scope and Limitation of the Study}

The study is limited on the Plastiknology development and utilization among Persons with Disability (PWD) in Sinacaban, Misamis Occidental. The respondents of the study were seventeen (17) functional Persons with Disability (PWDs). Wherein, one has hearing impairment, four are visually impaired and 12 have orthopedic impairments. The study utilized common household wastes such as coffee sachets, juice sachets, plastic bags, etc. with the application of handicrafts techniques in Oripoly, Macrame, and Crochet.

\section{Materials and Methods}

The study utilized polyethylene wastes such as coffee sachets, plastic bags, and other common wastes as material resource.

The study made use of mixed method research design specifically, sequential exploratory design, where quantitative data and data analysis are used first, then the finding of quantitative results are reinforced with qualitative data and data analysis.

This research study quantitative data first as used in descriptive research, according to Creswell (2003) maintained that descriptive research is an approach which the inquirer often makes knowledge claims based primarily on constructivist perspectives are constructed with as intent of participatory perspectives in quantitative perspective and data analysis. This study will then use Qualitative data analysis through the training module in plastiknology for PWDs outcome of the study: training and product evaluation to further reinforce, deepen and clarify quantitative results. Research Setting.

The study was conducted at the Municipality of Sinacaban, Misamis Occidental with Barangay's key officials.

\subsection{The Respondents of the Study}

The study made use of purposive with strategic approach. The respondents of the study were seventeen (17) Persons' with Disability at the Municipality of Sinacaban, Misamis Occidental.

\subsection{Research Instrument}

For the purpose of the study, the researcher made use of a research made instrument on: process variables on pre-assessment of clients' participation, tardiness, cooperative capacity, awareness of the global scenario on greenhouse effect, sanitation, sorting and cutting, folding and connecting; post-assessment on clients' awareness of the global scenario on greenhouse effect and outcomes based on the training evaluation and product evaluation. A researcher made instruments also was utilized to gather respondents' profile; age, gender, civil status, types of disability, interest in handicrafts and attendance in various livelihood trainings. 
The researcher secured permission to administer the survey from the respondents or the PWDs (Persons with Disability). A letter written in their dialect was read and explained to the respondents for the said purpose before the plastiknology training begun.

Upon approval, the researcher conducted the training. During the conduct of evaluation, selected students and teachers assisted the researcher disseminate the survey questionnaires to the Persons with Disability (PWDs).

Each item on the questionnaires thoroughly explained one by one and each was given enough assistance needed in collecting the answers of the respondents.

The study made use of descriptive statistics; mean, standard deviation, frequency, percentage and percentage distribution on all variables, dependent and independent. The researcher made use of inferential statistic, T-test to compare Pre self-assessment and Post evaluators assessment, and regression analysis be used to test on how much of the input and process variable explain the output of the study.

\section{Findings}

1) Seventy-six percent (76\%) of the respondents are female and are above 40 years old. All of the respondents are classified as functional and majority fifty-three percent of the respondents are married who have undergone 1 to 2 livelihood trainings.

2) Majority fifty-three percent (53\%) of the respondents agree that they are have interest in handicrafts. The over-all rating is also at agree (mean=3.06). The standard deviation of 0.83 indicates that the respondent's level of interest in handicrafts varies a lot from each other.

3) Fifty-nine percent (59\%) of the respondents strongly disagree to disagree that they are have background in handicrafts. The over-all rating is also at disagree and the respondent's level of background in handicrafts categorically varies from each other.

4) All of the respondents are present in the two-day training. And the data further shows that majority fifty-three percent are present on time during the said training.

5) Majority fifty-nine percent of the respondents agree that they are have cooperative capacity. The over-all rating is also at agree and the respondent's level of cooperative capacity is somehow similar or close to each other.

6) Sixty-five percent of the respondents agree that they are have awareness global scenario in greenhouse effect. The over-all rating is also at agree and the respondent's level global scenario in greenhouse effect is similar to each other.

7) Majority sixty-nine percent of the respondents strongly agree that they are have sanitation skills. The over-all rating is at agree and the respondent's level of sanitation is similar to each other.

8) Sixty-one percent $(61 \%)$ of the respondents agree that they are have sorting skills. The over-all rating is at agree and the respondent's level of sorting is similar to each other.

9) Majority sixty-five percent of the respondents agree that they have folding skills. The overall rating is at agree and the respondent's level of sorting is similar to each other. 
10) Majority seventy-six percent of the respondents agree that they are have connecting skills. The over-all rating is at agree and the respondents level of connecting is similar to each other.

11) Majority fifty-three percent of the evaluators evaluated the respondents with agree in terms of sanitation. The over-all rating is at agree and the respondents level of sanitation as evaluated is similar to each other.

12) Majority fifty-eight percent of the evaluators evaluated the respondents with agree in terms of sorting. The over-all rating is at agree and the respondents level of sorting as evaluated is similar to each other.

13) Majority fifty-three percent of the evaluators evaluated the respondents with strongly agree in terms of folding. The over-all rating is at agree and the respondents level of folding as evaluated is similar to each other.

14) Majority fifty-three percent of the evaluators evaluated the respondents with strongly agree in terms of connecting. The over-all rating is at agree and the respondents level of connecting as evaluated is similar to each other.

15) There is no significant difference in the respondents' skills pre-self-assessment and postevaluators- assessment is accepted. The result indicates that there that there is no significant difference in respondents, sanitation, sorting and cutting, folding and connecting skills when grouped according pre-self-assessment and post-evaluators-assessment.

16) Regression model is not significant. The null hypothesis is accepted. This signifies that the input and process variable of the study have no significant effect on respondents' output variable, post-evaluation.

17) The value of adjusted coefficient of multiple determination is 0.32 which explains that $32 \%$ of the total variation of respondents' output variable, post evaluation is explained by the variation of input and process variable; Age Gender, Civil status, Interest, Background, Awareness and Pre-self-assessment. The remaining 68\% percent can be explained by other reasons or variables.

\section{Results and Discussions}

In this chapter the results of the data analysis are presented. The data were collected and then processed in response to the problems posed in chapter 1 of this study.

Problem 1. What is the input variable of the study in terms of:

- Age

- Gender

- Civil status

- Types of disability

- Attendance in previous livelihood trainings

- Interest in handicrafts

- Background in handicrafts 
Table 1: Distribution of statistics frequency and percentage distribution of respondents' characteristics in terms of age, gender, civil status and disability and attendance in various trainings

\begin{tabular}{|l|l|l|l|}
\hline Variables & Specifications & Frequency \\
\hline \multirow{5}{*}{ Age } & 40 and above & 13 & $76.47 \%$ \\
\cline { 2 - 4 } & $29-40$ & 1 & $5.88 \%$ \\
\cline { 2 - 4 } & $19-30$ & 1 & $5.88 \%$ \\
\cline { 2 - 4 } & $17-18$ & 1 & $5.88 \%$ \\
\cline { 2 - 4 } & $14-16$ & 1 & $5.88 \%$ \\
\cline { 2 - 4 } & 13 and below & 0 & $0.00 \%$ \\
\hline \multirow{5}{*}{ Gender } & Total & 17 & $100.00 \%$ \\
\hline \multirow{5}{*}{ Civil Status } & Female & 13 & $76.47 \%$ \\
\cline { 2 - 4 } & Male & 4 & $23.53 \%$ \\
\hline \multirow{5}{*}{ Disability } & Total & 17 & $100.00 \%$ \\
\hline & Separated & 0 & $0.00 \%$ \\
\cline { 2 - 4 } & Married & 9 & $52.94 \%$ \\
\cline { 2 - 4 } & Single & 8 & $47.06 \%$ \\
\hline & Total & 17 & $100.00 \%$ \\
\hline \multirow{5}{*}{ Attendance in various training } & Hearing impairment & 1 & $5.88 \%$ \\
\cline { 2 - 4 } & Orthopedic impairment & 12 & $70.58 \%$ \\
\cline { 2 - 4 } & Visual impairment & 4 & $23.52 \%$ \\
\cline { 2 - 4 } & Functional & 17 & $100.00 \%$ \\
\cline { 2 - 4 } & Not-functional & 0 & $0.00 \%$ \\
\hline & Total & 17 & $100.00 \%$ \\
\hline & $5-6$ & 2 & $11.76 \%$ \\
\cline { 2 - 4 } & $3-4$ & 3 & $17.65 \%$ \\
\cline { 2 - 4 } & $1-2$ & 9 & $17.65 \%$ \\
\hline & Total & $52.94 \%$ \\
\hline & & $100.00 \%$ \\
\hline
\end{tabular}

Table 1 shows that $76 \%$ of the respondents is female and is above 40 years old. $5.88 \%$ of the respondents have hearing impairment, $70.58 \%$ have orthopedic impairment, and $23.52 \%$ are visually impaired. All of the respondents are classified as functional and $53 \%$ of the respondents are married who have undergone 1 to 2 livelihood trainings.

Table 2: Distribution of statistics frequency, percentage distribution, mean standard deviation of respondents' interest in handicrafts

\begin{tabular}{|l|l|l|l|l|l|l|l|}
\hline Indicators & SA & A & D & SD & Mean & StDev & Description \\
\hline I like handicrafts & 8 & 7 & 0 & 2 & 3.24 & 0.97 & Agree \\
\hline I enjoy watching people doing handicrafts & 7 & 7 & 1 & 2 & 3.12 & 0.99 & Agree \\
\hline I have tried making handicraft products & 5 & 7 & 2 & 3 & 2.82 & 1.07 & Agree \\
\hline
\end{tabular}

Legend: SA strongly agree, A agree, D disagree, SD strongly disagree, Stdev standard deviation

The data above showed $53 \%$ of the respondents agreed that they have interest in handicrafts. The over-all rating was also at agree (mean=3.06). The standard deviation of 0.83 indicated that the respondents level of interest in handicrafts varied a lot from each other. 
The respondents are very interested in handicrafts. However, the standard deviation indicated that it varies a lot from each other. This is because some respondents strongly disagree in each indicator. In fact, two to three respondents indicated that strongly agree that they like, enjoy or tried handicraft. But this is normal in pre-training.

Table 3: Distribution of statistics frequency, percentage distribution, mean standard deviation of respondents' background in handicrafts

\begin{tabular}{|l|l|l|l|l|l|l|l|}
\hline Indicators & SA & A & D & SD & Mean & StDev & Description \\
\hline I have made handicrafts displayed at home & 5 & 4 & 4 & 4 & 2.59 & 1.18 & Disagree \\
\hline $\begin{array}{l}\text { I have made handicrafts that I have sold } \\
\text { locally }\end{array}$ & 6 & 3 & 5 & 3 & 2.71 & 1.16 & Disagree \\
\hline $\begin{array}{l}\text { I have made handicrafts that I have sold } \\
\text { nationally or internationally }\end{array}$ & 4 & 3 & 5 & 5 & 2.35 & 1.17 & Disagree \\
\hline
\end{tabular}

Legend: SA strongly agree, A agree, D disagree, SD strongly disagree, Stdev standard deviation

The data above revealed that $47.06 \%$ of the respondents disagreed on having background in handicrafts. The over-all rating was also at disagree (mean=2.55). The standard deviation of 0.64 indicated that the respondents' level of background in handicrafts categorically varied from each other.

Based on the data, it showed that the respondents have very minimal background on handicrafts. The study conducted by C.M.Reyes, A.D. Tabuga, et al. has been an instrument of providing facilities, training materials and technical aids for Person with Disability (PWD) students where feasible. However, 4-6 respondents strongly agree on statements I have

made handicrafts displayed at home, I have made handicrafts that I have sold locally and I have made handicrafts that I have sold nationally or internationally. But 3-5 respondents also strongly disagree to the same statement.

Problem 2. What is the level of participation of PWD's in the development of Plastiknology in terms of:

Tardiness

Cooperative capacity

Awareness of the global scenario in greenhouse effect

Table 4: Distribution of statistics frequency and percentage distribution of respondents' attendance in training and tardiness

\begin{tabular}{|l|l|l|l|}
\hline Variables & Specifications & Frequency & Percentage \\
\hline \multirow{4}{*}{ Attendance in training } & Present in two-day training & 17 & $100.00 \%$ \\
\cline { 2 - 4 } & Present on the first day & 0 & $0.00 \%$ \\
\cline { 2 - 4 } & Total & 17 & $100.00 \%$ \\
\hline \multirow{3}{*}{ Tardiness } & On time & 9 & $52.94 \%$ \\
\cline { 2 - 4 } & Tardy & 8 & $47.06 \%$ \\
\cline { 2 - 4 } & Total & 17 & $100.00 \%$ \\
\hline
\end{tabular}


The data above showed that all of the respondents were present in the two-day training. And the data further revealed that $53 \%$ of the respondents was present and came on time during the said training.

Table 5: Distribution of statistics frequency, percentage distribution, mean standard deviation of respondents' cooperative capacity

\begin{tabular}{|l|l|l|l|l|l|l|l|}
\hline Indicators & SA & A & D & SD & Mean & StDev & Description \\
\hline I can work with other participants & 6 & 6 & 5 & 0 & 3.06 & 0.83 & Agree \\
\hline I can work with other participants easily & 9 & 7 & 1 & 0 & 3.47 & 0.62 & Agree \\
\hline $\begin{array}{l}\text { I can work with other participants } \\
\text { effectively }\end{array}$ & 10 & 7 & 0 & 0 & 3.59 & 0.51 & Agree \\
\hline
\end{tabular}

Legend: SA strongly agree, A agree, D disagree, SD strongly disagree, Stdev standard deviation

The data showed $59 \%$ of the respondents agree that they had cooperative capacity. The over-all rating was also at agree $(m e a n=3.37)$. The standard deviation of 0.51 indicated that the respondents' level of cooperative capacity was somehow similar or close to each other.

Table 6: Distribution of statistics frequency, percentage distribution, mean standard deviation of respondents' awareness of the global scenario in greenhouse effect

\begin{tabular}{|l|l|l|l|l|l|l|l|}
\hline Indicators & SA & A & D & SD & Mean & StDev & Description \\
\hline $\begin{array}{l}\text { I am aware that there is a great/massive } \\
\text { change in climate }\end{array}$ & 11 & 6 & 0 & 0 & 3.65 & 0.49 & Agree \\
\hline $\begin{array}{l}\text { I am aware that the problem in climate is } \\
\text { not just in our area but across the world }\end{array}$ & 11 & 6 & 0 & 0 & 3.65 & 0.49 & Agree \\
\hline $\begin{array}{l}\text { I am aware that there are chemical that are } \\
\text { destroying the ozone layer }\end{array}$ & 11 & 5 & 1 & 0 & 3.59 & 0.62 & Agree \\
\hline
\end{tabular}

Legend: SA strongly agree, A agree, D disagree, SD strongly disagree, Stdev standard deviation

The data showed that $65 \%$ of the respondents agree that they had awareness on global scenario in greenhouse effect. The over-all rating was also at agree (mean=3.63). The standard deviation of 0.53 indicated that the respondents level global scenario in greenhouse effect was similar to each other.

Problem 3. What is the Pre-self-assessment and Post-evaluators assessment of the respondents in terms of:

- 3.1 Sanitation

- $\quad 3.2$ Sorting and Cutting

- 3.3 Folding

- 3.4 Connecting

Table 7: Distribution of statistics frequency, percentage distribution, mean standard deviation of respondents' pre-self-assessment on sanitation

\begin{tabular}{|l|l|l|l|l|l|l|l|}
\hline Indicators & SA & A & D & SD & Mean & StDev & Description \\
\hline I can clean my area of work & 11 & 6 & 0 & 0 & 3.65 & 0.49 & Agree \\
\hline $\begin{array}{l}\text { I use sanitation materials before starting to } \\
\text { work }\end{array}$ & 11 & 6 & 0 & 0 & 3.65 & 0.49 & Agree \\
\hline
\end{tabular}




\begin{tabular}{|l|l|l|l|l|l|l|l|}
\hline $\begin{array}{l}\text { I know how to separate clean from un-clean } \\
\text { materials }\end{array}$ & 10 & 7 & 0 & 0 & 3.59 & 0.51 & Agree \\
\hline
\end{tabular}

Legend: SA strongly agree, A agree, D disagree, SD strongly disagree, Stdev standard deviation

The data showed $59 \%$ of the respondents "strongly agreed" that they had sanitation skills. The over-all rating was at agree (mean=3.63). the standard deviation of 0.48 indicated that the respondents' level of sanitation was similar to each other.

Table 8: Distribution of statistics frequency, percentage distribution, mean standard deviation of respondents' pre-self-assessment sorting

\begin{tabular}{|l|l|l|l|l|l|l|l|}
\hline Indicators & SA & A & D & SD & Mean & StDev & Description \\
\hline I can sort and cut materials & 8 & 9 & 0 & 0 & 3.47 & 0.51 & Agree \\
\hline I can sort and cut materials effectively & 6 & 11 & 0 & 0 & 3.35 & 0.49 & Agree \\
\hline $\begin{array}{l}\text { I can sort and cut materials while } \\
\text { minimizing waste }\end{array}$ & 5 & 12 & 0 & 0 & 3.29 & 0.47 & Agree \\
\hline
\end{tabular}

Legend: SA strongly agree, A agree, D disagree, SD strongly disagree, Stdev standard deviation

The data above showed $71 \%$ of the respondents "agree" that they had sorting skills. The over-all rating was at agree (mean=3.37). the standard deviation of 0.45 indicated that the respondents' level of sorting was similar to each other.

Table 9: Distribution of statistics frequency, percentage distribution, mean standard deviation of respondents' pre-self-assessment folding

\begin{tabular}{|l|r|r|r|r|r|r|c|}
\hline \multicolumn{1}{|c|}{ Indicators } & SA & A & D & SD & Mean & StDev & Description \\
\hline I can fold materials & 8 & 9 & 0 & 0 & 3.47 & 0.51 & Agree \\
\hline $\begin{array}{l}\text { I can fold materials according to what is } \\
\text { required }\end{array}$ & 7 & 10 & 0 & 0 & 3.41 & 0.51 & Agree \\
\hline $\begin{array}{l}\text { I can fold materials while minimizing } \\
\text { waste }\end{array}$ & 6 & 10 & 0 & 1 & 3.24 & 0.75 & Agree \\
\hline
\end{tabular}

Legend: SA strongly agree, A agree, D disagree, SD strongly disagree, Stdev standard deviation

The data above showed $65 \%$ of the respondents "agree" that they had folding skills. The over-all rating was at agree $($ mean $=3.37)$. The standard deviation of 0.50 indicated that the respondents level of sorting was similar to each other.

Table 10: Distribution of statistics frequency, percentage distribution, mean standard deviation of respondents' pre-self-assessment connecting

\begin{tabular}{|l|l|l|l|l|l|l|l|}
\hline Indicators & SA & A & D & SD & Mean & StDev & Description \\
\hline I can connect materials & 4 & 12 & 1 & 0 & 3.18 & 0.53 & Agree \\
\hline $\begin{array}{l}\text { I can connect material is a according to } \\
\text { what is required }\end{array}$ & 7 & 9 & 1 & 0 & 3.35 & 0.61 & Agree \\
\hline $\begin{array}{l}\text { I can connect material while minimizing } \\
\text { waste }\end{array}$ & 8 & 9 & 0 & 0 & 3.47 & 0.51 & Agree \\
\hline
\end{tabular}

Legend: SA strongly agree, A agree, D disagree, SD strongly disagree, Stdev standard deviation 
The data above showed $76 \%$ of the respondents "agree" that they had connecting skills. The overall rating was at agree (mean=3.33). The standard deviation of 0.46 indicated that the respondents' level of connecting was similar to each other.

Table 11: Distribution of statistics frequency, percentage distribution, mean standard deviation of respondents' post evaluator assessment sanitation

\begin{tabular}{|l|l|l|l|l|l|l|l|}
\hline Indicators & SA & A & D & SD & Mean & StDev & Description \\
\hline The participant can clean my area of work & 8 & 9 & 0 & 0 & 3.47 & 0.51 & Agree \\
\hline $\begin{array}{l}\text { The participant use sanitation materials before } \\
\text { starting to work }\end{array}$ & 9 & 8 & 0 & 0 & 3.53 & 0.51 & Agree \\
\hline $\begin{array}{l}\text { The participant know how to separate clean } \\
\text { from un-clean materials }\end{array}$ & 9 & 8 & 0 & 0 & 3.53 & 0.51 & gree \\
\hline
\end{tabular}

Legend: SA strongly agree, A agree, D disagree, SD strongly disagree, Stdev standard deviation

The data above showed 53\% of the respondents earned "agree" from the evaluators who evaluated them in terms of sanitation. The over-all rating was at agree (mean=3.51). The standard deviation of 0.50 indicated that the respondents' level of sanitation as evaluated was similar to each other.

Based on the data, evaluators assessed the respondents of the study to have a sense of sanitation. The participant cleaned the area of work, they also used sanitation materials before starting to work and separated clean from un-clean materials. However, the rate differs in terms of agreeing to the statements whether it is strongly agree or agree.

Table 12: Distribution of statistics frequency, percentage distribution, mean standard deviation of respondents' post evaluator assessment sorting

\begin{tabular}{|l|l|l|l|l|l|l|l|}
\hline Indicators & SA & A & D & SD & Mean & StDev & Description \\
\hline The participant can sort and cut materials & 10 & 7 & 0 & 0 & 3.59 & 0.51 & Agree \\
\hline $\begin{array}{l}\text { The participant can sort and cut materials } \\
\text { effectively }\end{array}$ & 7 & 10 & 0 & 0 & 3.41 & 0.51 & Agree \\
\hline $\begin{array}{l}\text { The participant can sort and cut materials } \\
\text { while minimizing waste }\end{array}$ & 10 & 7 & 0 & 0 & 3.59 & 0.51 & Agree \\
\hline
\end{tabular}

Legend: SA strongly agree, A agree, D disagree, SD strongly disagree, Stdev standard deviation

The data above showed $58 \%$ of the respondents were evaluated with "agree" in terms of sorting. The over-all rating was at agree (mean=3.53). The standard deviation of 0.47 indicated that the respondents' level of sorting as evaluated was similar to each other

Table 13: Distribution of statistics frequency, percentage distribution, mean standard deviation of respondents' post evaluator assessment folding

\begin{tabular}{|l|l|l|l|l|l|l|l|}
\hline Indicators & SA & A & D & SD & Mean & StDev & Description \\
\hline The participant can fold materials & 9 & 8 & 0 & 0 & 3.53 & 0.51 & Agree \\
\hline $\begin{array}{l}\text { The participant can fold materials } \\
\text { according to what is required }\end{array}$ & 9 & 8 & 0 & 0 & 3.53 & 0.51 & Agree \\
\hline
\end{tabular}




\begin{tabular}{|l|l|l|l|l|l|l|l|}
\hline $\begin{array}{l}\text { The participant can fold materials while } \\
\text { minimizing waste }\end{array}$ & 9 & 8 & 0 & 0 & 3.53 & 0.51 & Agree \\
\hline
\end{tabular}

Legend: SA strongly agree, A agree, D disagree, SD strongly disagree, Stdev standard deviation

The data above showed 53\% of the respondents were evaluated with "strongly agree" in terms of folding. The over-all rating was at agree (mean=3.53). The standard deviation of 0.51 indicated that the respondents' level of folding as evaluated was similar to each other.

Table 14: Distribution of statistics frequency, percentage distribution, mean standard deviation of respondents' post evaluator assessment connecting

\begin{tabular}{|l|l|l|l|l|l|l|l|}
\hline Indicators & SA & A & D & SD & Mean & StDev & Description \\
\hline The participant can connect materials & 9 & 8 & 0 & 0 & 3.53 & 0.51 & Agree \\
\hline $\begin{array}{l}\text { The participant can connect material is a } \\
\text { according to what is required }\end{array}$ & 9 & 8 & 0 & 0 & 3.53 & 0.51 & Agree \\
\hline $\begin{array}{l}\text { The participant can connect material while } \\
\text { minimizing waste }\end{array}$ & 9 & 8 & 0 & 0 & 3.53 & 0.51 & Agree \\
\hline
\end{tabular}

Legend: SA strongly agree, A agree, D disagree, SD strongly disagree, Stdev standard deviation

The data above showed $53 \%$ of the respondents were evaluated with a rating of "strongly agree" in terms of connecting. The over-all rating was at agree (mean=3.53). The standard deviation of 0.51 indicated that the respondents' level of connecting as evaluated was similar to each other.

This implies the different competencies that will be taught to Persons with Disability such as Sanitation, Sorting and Cutting, Folding, and Connecting allowed them to produce innovative products leading to "Green Business" empowered with Social Responsibility mindset. This could be a "niche" for our PWDs to become game changers and thought leaders.

Sharing similar results is the Case study "Visually impaired village women demonstrate how the disabled can be successful in enterprise development and become community leaders" ('A handbook for training of disabled on rural enterprise development', n.d.), that suggested Training in enterprise development offers a good opportunity for women with disabilities. Further suggesting, small-scale enterprise development allows both women and men with disabilities to earn a living close to home. Such was the case of Nuan Sarachan, 49-year-old visually impaired Thai from the Roi-et province in Thailand who has shown how rehabilitation training and sound business sense enabled persons with disabilities become economically independent.

Problem 4. Is there a significant difference between Pre-self-assessment and Post evaluators assessment of the respondent in terms of: sanitation, sorting and cutting, folding, connecting?

Table 15: Distribution of statistic (two tailed T-test) in respondents' training skills when according to pre-self-assessment and post evaluators assessment

\begin{tabular}{|l|l|l|l|l|}
\hline Category & \multicolumn{2}{|l|}{ Groups } & P-value & T stat \\
\hline & Pretest $\mathrm{n}=17$ & Posttest $\mathrm{n}=17$ & & \\
\hline Sanitation & Mean=3.62 & Mean=3.50 & 0.2458 & $-0.695 \mathrm{NS}$ \\
\hline Sorting and cutting & Mean=3.37 & Mean=3.52 & 0.1656 & $0.986 \mathrm{NS}$ \\
\hline Folding & Mean=3.37 & Mean=3.52 & 0.1866 & $0.902 \mathrm{NS}$ \\
\hline Connecting & Mean=3.33 & Mean=3.52 & 0.1242 & $1.175 \mathrm{NS}$ \\
\hline
\end{tabular}


The table 15 showed the distribution of statistics (two tailed T-test) in respondents training skill when grouped according to pre-self-assessment and post-evaluators-assessment. There were two groups being compared and based on a two-tailed $t$-test the data showed that the null hypothesis "there is no significant difference in the respondents' skills pre-self-assessment and postevaluators-assessment" was accepted. The result indicated that there was no significant difference in the respondents' sanitation, sorting and cutting, folding and connecting skills when grouped according pre-self-assessment and post-evaluators-assessment.

This is because since the respondents are PWD's, they have the tendencies to repeat previous instruction. What was taught to them at the very beginning of the training was continually practiced till the training ended. However, in terms of sanitation though not significant, post evaluation is lesser than the pre-self-assessment. This may be due, because on the second day of the training, when products are already made and culminating activity is already set in place. The respondents failed to clean their work spaces as they go.

Persons with Disability to venture on plastic handicrafts, or Plastiknology into business. A concrete example to this is the study of New Jersey Waste Business Network update in 2015 wherein recycling in New Jersey is an important segment of the state's economy and one that employs approximately 27 thousand people. On a national scale, recycling has encouraged the growth of an industry and created jobs. What is even more important to the generators of waste; however, are the dollar savings that can be realized through recycling.

Nevertheless, coffee sachets and plastic bags are products of plastics which are used widely for various purposes such as packaging of coffee, powdered beverages and packaging materials for a wide variety of items. These can pose a great environmental problem if not disposed properly thereby clogging drains and blocking the free flow of water then leading to flooding.

Problem 5. To what extent does input and process variables explain the output variable?

Table 16: Multiple linear regression analysis between the whole set of input and process variable and respondent output variable, post evaluation

\begin{tabular}{|l|l|l|l|}
\hline Independent variable & Regression coefficient & P-Value & T- Value \\
\hline Age & 0.08 & 0.4401 & $0.807 \mathrm{NS}$ \\
\hline Gender & 0.19 & 0.4931 & $0.714 \mathrm{NS}$ \\
\hline Civil status & -0.40 & 0.1657 & $-1.508 \mathrm{NS}$ \\
\hline Interest & 0.04 & 0.8074 & $0.250 \mathrm{NS}$ \\
\hline Background & 0.16 & 0.4763 & $0.743 \mathrm{NS}$ \\
\hline Awareness & 0.48 & 0.3955 & $0.892 \mathrm{NS}$ \\
\hline Pre-self-assessment & 0.16 & 0.8142 & $0.241 \mathrm{NS}$ \\
\hline
\end{tabular}

NS Not significant

Constant: 2.06

Adjusted R: 0.32

F- Value: 2.05

P-value: 0.1556

Significance Level: Not significant 
The Table above showed that the regression model was not significant. The null hypothesis was accepted. This signifies that the input and process variable of the study have no significant effect on respondents' output variable, post-evaluation.

The value of adjusted coefficient of multiple determination was 0.32 which explained that $32 \%$ of the total variation of respondents' output variable, post evaluation was explained by the variation of input and process variable; Age, Gender, Civil status, Interest, Background, Awareness and Preself-assessment. The remaining $68 \%$ percent can be explained by other reasons or variables.

Problem 6. What are the innovated products generated and developed by PWD's?

\section{Coin Purse}

It is estimated to collect 40 used coffee sachets in order to produce a handy purse. After folding, connecting, strengthening and attaching the zipper or magnetic lock, one purse is estimated to have four hours production time.

\section{Clutch Bag}

The clutch bag is intended for gentlemen and ladies' use. It requires 100 wastes (coffee sachets) in order to produce one in more or less one day.

\section{Wallet}

The wallet is designed to meet the needs of most ladies who wanted to carry the most necessary only on a walk to the store or to church. It can already contain a cellphone, cards, keys, and some cash. But you need to gather more or less 120 wastes of sachets (coffee, juice, etc.) in order to make one while on a weekend or on a long trip because you need more or less a day and a half to finish one elegant wallet.

\section{Place Mat}

No matter how busy life is, we always take time to sit and dine. A placemat is a comfortable partner whether in a table or in a park on a picnic. This needs 600 sachets.

\section{Wall Organizer}

The wall organizer collects all your important little things in a corner by hanging, making visible everything every time. This organizer can be produced using more or less 600 used sachets. This may need sometime depending on how fast your skill in folding and connecting have gone. Your base holders must be formed first before attaching them to the pad. This can be done in two days.

\section{Conclusions and Recommendations}

The training has been very successful. Quantitative data had provided description of the respondents and the training itself. Though in parametric data analysis, T-test comparison between pre-self-assessment and post-evaluation made no significant difference. And the regression model was also not significant. Qualitative results based on the innovated products of the PWD respondents are very promising, and well-constructed. They can use the skills they have learned in producing handicrafts as their alternative livelihood. And since they are using recycled materials, total waste management would likely be implemented in the community. 
On the basis of the findings, the following recommendations are presented.

1) National and Local Institutions provide livelihood assistance to special sectors such as persons with disability. Facilitate in the continuity of the program and livelihood.

2) In consonance to this, the government thru State Colleges and Universities has to provide special facilities for PWDs as well as the necessary financial resources.

3) For the University/Administration to facilitate in achieving the University's Vision on research and extension by having a clear sustainable plan in the extension division is suggested to include livelihood activities and the like to Persons with Disability (PWDs).

4) Technology Teachers enhance awareness on how the present issues on environment and waste management be resolved and at the same time, recognize the capability of persons with disability (PWDs) to improve self-worth and livelihood skills in order to gain independence and improve way of life.

5) Significant Others. To gain support from because Person with Disability (PWDs) cannot do it without the help of those who serve as their primary source of inspiration and motivation.

Persons with Disability (PWDs). The study recognizes the capability of persons with disability (PWDs) to improve self-worth by acquiring livelihood skills in order to become small scale entrepreneurs by producing and designing more plastiknology products. Eventually, become trainers to fellow PWDs and gain independence and improve way of life.

\section{References}

[1] Antonio, Lisa, C. (2010) Study on Recyclables Collection Trends and Best Practices in The Philippines. Philippine Business for Environment, Philippines.

[2] Art, M. 2013. Macrame Pattern Book. Martin Griffin

[3] Basketry. (n.d.). Retrieved March 20, 2015, from http://www.historythrougharts.org/main/program/./PF_Basketry.pdf.

[4] Bautista, Riz (2017). Shredded Polyvinyl Chloride as Substitute for the Coarse Aggregate in the Production of Paver, unpublished thesis, USTP, Cagayan de Oro City, Philippines

[5] Belen, H. 1952. Philippine Creative Handicrafts. Philippine Education

[6] Belen, H. 1952. Philippine Creative Handicrafts. Philippine Education. "how Products Are Made". (n.d.). Retrieved March 20, 2015, from http://www.madehow.com/Volume4/Basket.html\#ixzz3Ou1le75H.

[7] Carpenter, Edward J., et al. Surface. Vol. 175, Issue 4027, pp. 1240-1241. Retrived from: http://science.sciencemag.org/content/175/4027/1240

[8] Castillo, Alicia (2001) (JICA Waste Characterization Study, 1997).

[9] Crispin, F. Dictionary of Technical Terms, Bruce Publishing Co., 1952

[10] Debb, E. V. First Step in Weaving.

[11] D.S. Achilias, C. Roupakias, P. Megalokonomosa, A.A. Lappas, E.V, Antonakou (Chemical Recycling of Wastes made from Polyethylene (LDPE and HDPE) and Polypropylene (PP)

[12] Ecological Solid Waste Act: Environmental Protection through Proper Solid Waste

[13] Fundamentals of Teaching Industrial Arts in the Philippine Public Schools, E. F. David \& Sons, Manila, 1951.

[14] Griswold Lester, Handicraft Procedure and Projects, Prentice Hall, Inc. 1948.

[15] "Handout" 'Laguna Coco By-Products, Inc. 1964.

[16] Hopewell, Jefferson, et.al. (2009) (Philos Trans R Soc Soc Land B Bial Sci. by the Royal Society Publishing, c. 2009) 
[17] "How to Package a Product - Making Society". (2013, June 26). Retrieved March 20, 2015, from http://makingsociety.com/2013/06/how-to-package-a-product/.

[18] Hutchins, Marbel Reagh, Creative Handicraft, Sentinel-Books Publisher, Arts Crafts Education, New York. 1944.

[19] Johnson, William H. and Newkirk, Louis V. The Graphic Arts, The Macmillan Co, New York, 1942.

[20] "Macrame Increases Fine Motor Skills and Dexterity." Macrame Patterns \& Macrame Instructions. N.p., n.d. Web. 20 Mar. 2015.

[21] Moore Frank C. Handicraft For Elementary Schools, D. C. Health and Co., 1953.

[22] Olson, Delamr W. Industrial Arts for The General Shop, Prentice-hall, Inc. Englewood Cliffs, N. J. 1958.

[23] Parfitt (2002) and USEPA (2008) Plastic Waste Management in the Context of a European Recycling Society: Comparing Results and Uncertainties in a Life Cycle Perspectives

[24] "Plastic Today, The Dow Chemical Co., Midland, Michigan, 1952.

[25] PWP - splash. (n.d.). Retrieved March 20, 2015, from http://publish.comcast.net/. .

[26] Recycling Society: Comparing Results and Uncertainties in a Life Cycle Perspectives

[27] Regala Pantaleon, Handbook For Woodworks, Manila, Philippines, 1937

[28] Suarez, KD. PH among Top Nations dumping plastic into sea. Published February 13, 2015. Retrieved from: https://www.rappler.com/science-nature/environment/83759-amount- plasticwastes-oceans-study

[29] Tenner \& DeToro. 2018. “Garvin's Eight Dimensions of Product Quality.” Total Quality Management.

[30] “Types of Basket Weaving.” (2013, May 12). Retrieved March 20, 2015 From http://www.savvyhomemade.com/types-of-basket-weaving/.

*Corresponding author.

E-mail address: liberty.doncillo@ ustp.edu.ph 